\title{
Erratum
}

\section{A Mild and Efficient Synthesis of Buta-1,3-dienes Substituted with a Terminal Pentafluoro- $\lambda^{6}$-sulfanyl Group}

Maxim V. Ponomarenko, * Yurii A. Serguchev, Gerd-Volker Röschenthaler* Synthesis 2010, 3906.

For the reaction of compounds $\mathbf{3 a}, \mathbf{b}$ with bromine according to Scheme 4, we had observed that the corresponding dibromides $\mathbf{4 a}, \mathbf{b}$ were obtained. However, we have since encountered difficulties in providing a suitable explanation for the mechanism of bisdehydrobromination of $\mathbf{4 a}, \mathbf{b}$ leading to the formation 1,3-dienes $\mathbf{5 a}, \mathbf{b}$ (Scheme 6). Moreover, it has been reported that tertiary hydrogens in benzylic and allylic systems are quite reactive toward molecular bromine or $N$-bromosuccinimide, but in all such cases, an initiator - either irradiation or high temperature - was used. ${ }^{1}$ These points led us to continue the investigation of the bromination reactions of olefins $\mathbf{3 a}, \mathbf{b}$.

We have thus re-examined the bromination of $\mathbf{3 a}, \mathbf{b}$ with molecular bromine in pentane, according to the procedure described in our previous paper, and have studied the reaction of 3a with $N$-bromosuccinimide in carbon tetrachloride using $m$-chloroperoxybenzoic acid as an initiator. The latter system was used to exclude the possible formation of 4a. However, under both conditions, the same product was obtained (NMR analysis), which had been determined previously to be the dibromide $\mathbf{4 a}$ according to elemental analysis and MS data. The peaks, namely $m / z(\%)=393(10)[\mathrm{M}-\mathrm{H}]^{+}, 395(15)[\mathrm{M}-\mathrm{H}+2]^{+}, 397$ (10) $[\mathrm{M}-\mathrm{H}+4]^{+}$, had been mistakenly interpreted by us as the molecular ion peaks of the dibromide 4a. In contrast, in a mass spectrum of product (7b) that was obtained after bromination of $\mathbf{3 b}$ (Scheme 8, i) we did not observe any characteristic molecular ions for structures $\mathbf{4 b}$ and $\mathbf{7 b}$. Therefore, the MS data is insufficient for proving the structures of the products $\mathbf{4 a}, \mathbf{b}$. The repetition of elemental analysis of the products, separated from the corresponding reaction mixtures after bromination of $\mathbf{3 a}, \mathbf{b}$ (Scheme $8, \mathrm{i}, \mathrm{ii}$ ), confirmed beyond any doubt the structures of the allylic bromination products 7a,b. More significantly, the ${ }^{13} \mathrm{C}$ and ${ }^{1} \mathrm{H}$ NMR are better correlated with the structures of $\mathbf{7 a}, \mathbf{b}$ than with those of $\mathbf{4 a}, \mathbf{b}$. The substituent $\mathrm{CH}=\mathrm{CHSF}_{5}$ in $\mathbf{7 a}, \mathbf{b}$ forms groups of multiplets in the ${ }^{1} \mathrm{H}$ NMR spectra similar to $\mathrm{SF}_{5}$-substituted olefins $4 \mathbf{c}, \mathbf{d}$, namely a doublet at $6.7 \mathrm{ppm}\left({ }^{\text {trans }} J_{\mathrm{HH}}=14.7 \mathrm{~Hz}\right)$ and a doublet of quintets at $6.52 \mathrm{ppm}$ with characteristic cou- pling constants $J_{\mathrm{HF}}=6 \mathrm{~Hz}$ and ${ }^{\text {trans }} J_{\mathrm{HH}}=14.7 \mathrm{~Hz}$ for the $\mathrm{CHSF}_{5}$ proton. Quintets for the carbon atoms of $\mathbf{7 a}, \mathbf{b}$, as well as $\mathbf{4 c , d}$, bound to the $\mathrm{SF}_{5}$ group and the carbon atoms $\beta$ to the $\mathrm{SF}_{5}$ group were observed in the ${ }^{13} \mathrm{C}$ NMR spectra with characteristic coupling constants ${ }^{2} J_{\mathrm{CF}}=20-21 \mathrm{~Hz}$ and ${ }^{3} J_{\mathrm{CF}}=6.7-7.7 \mathrm{~Hz}$ in the $135-144 \mathrm{ppm}$ region.

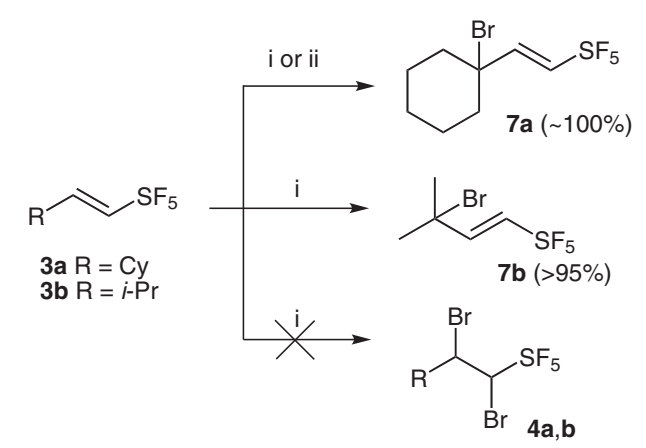

i: $\mathrm{Br}_{2}$ (1.2 equiv), pentane, 12 h, r.t.

ii: for 3a, NBS (1.1 equiv), $\mathrm{CCl}_{4}, \mathrm{MCPBA}$ (cat.), reflux, $6 \mathrm{~h}$

Scheme 8 Allylic bromination of $\mathbf{3 a}, \mathbf{b}$

The subsequent $\mathrm{HBr}$ elimination of $\mathbf{7 a}, \mathbf{b}$ after treatment with base gave the corresponding 1,3-dienes $\mathbf{5 a}, \mathbf{b}$ in good yields (Scheme 9). Consequently, the formation of $\mathbf{5 a}, \mathbf{b}$ is the result of 1,2-elimination similar to the dehydrobromination of $\mathbf{4 c , d}$ (Scheme 7).

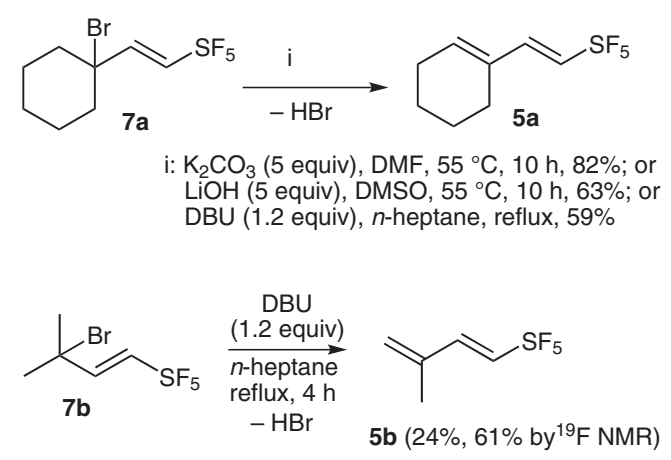

Scheme 9 Dehydrobromination of $7 \mathbf{a}, \mathbf{b}$ 
1-Bromo-1- $\left[(E)-2\right.$-(pentafluoro- $\lambda^{6}$-sulfanyl)vinyl $]$ cyclohexane (7a)

${ }^{1} \mathrm{H}$ NMR $\left(400 \mathrm{MHz}, \mathrm{CDCl}_{3}\right): \delta=6.75(\mathrm{~d}, J=14.7 \mathrm{~Hz}, 1 \mathrm{H}), 6.52$ (dquin, $\left.J_{\mathrm{HH}}=14.7 \mathrm{~Hz}, J_{\mathrm{HF}}=6.0 \mathrm{~Hz}, 1 \mathrm{H}\right), 2.00-2.30(\mathrm{~m}, 2 \mathrm{H}, \mathrm{Cy})$, 1.56-1.80 (m, 7 H, Cy), 1.29 (m, $1 \mathrm{H}, \mathrm{Cy}$ ).

${ }^{13} \mathrm{C} \mathrm{NMR}\left(100 \mathrm{MHz}, \mathrm{CDCl}_{3}\right): \delta=143.9$ (quin, $J=6.8 \mathrm{~Hz}$ ), 139.5 (quind, $J=20.8,1.5 \mathrm{~Hz}$ ), $66.1(\mathrm{CBr}), 39.7(\mathrm{Cy}), 25.3(\mathrm{Cy}), 23.2$ (Cy).

${ }^{19} \mathrm{~F} \mathrm{NMR} \mathrm{(376} \mathrm{MHz,} \mathrm{CDCl}_{3}$ ): $\delta=83.0$ (9 lines, A-part), 64.0 (dd, $J=150.3,6.0 \mathrm{~Hz}, \mathrm{~B}_{4}$-part).

MS (EI): $m / z(\%)=393(10), 395$ (15), 397 (10), 127 (100) [SF SF $81(42)[\mathrm{Br}]^{+}, 79(42)[\mathrm{Br}]^{+}$.

Anal. Calcd for $\mathrm{C}_{8} \mathrm{H}_{12} \mathrm{BrF}_{5} \mathrm{~S}$ : C, 30.49; H, 3.84; Br, 25.35; S, 10.18 . Found: C, 30.47; H, 3.88; Br, 25.02; S, 10.51 .

\section{(1E)-3-Bromo-3-methyl-1-(pentafluoro- $\lambda^{6}$-sulfanyl)but-1-ene} (7b)

${ }^{1} \mathrm{H}$ NMR $\left(400 \mathrm{MHz}, \mathrm{CDCl}_{3}\right): \delta=6.77(\mathrm{~d}, J=14.7 \mathrm{~Hz}, 1 \mathrm{H}), 6.52$ (dquin, $\left.J_{\mathrm{HH}}=14.7 \mathrm{~Hz}, J_{\mathrm{HF}}=6.0 \mathrm{~Hz}, 1 \mathrm{H}\right), 1.90\left(\mathrm{~s}, 6 \mathrm{H}, \mathrm{CH}_{3}\right.$ ).

${ }^{13} \mathrm{C} \mathrm{NMR}\left(100 \mathrm{MHz}, \mathrm{CDCl}_{3}\right.$ ): $\delta=144.1$ (quin, $J=6.7 \mathrm{~Hz}$ ), 138.6 (quin, $J=21.1 \mathrm{~Hz}$ ), $57.1(\mathrm{CBr}), 32.7\left(\mathrm{CH}_{3}\right)$.

${ }^{19} \mathrm{~F}$ NMR (376 MHz, $\mathrm{CDCl}_{3}$ ): $\delta=82.7$ (9 lines, A-part), 64.0 (dd, $J=150.3,6.0 \mathrm{~Hz}, \mathrm{~B}_{4}$-part).

MS (EI): $m / z(\%)=195(100)[\mathrm{M}-\mathrm{Br}]^{+}, 87$ (45), 67 (25) $[\mathrm{M}-\mathrm{HBr}$ $\left.-\mathrm{SF}_{5}\right]^{+}$.

Anal. Calcd for $\mathrm{C}_{5} \mathrm{H}_{8} \mathrm{BrF}_{5} \mathrm{~S}$ : C, 21.83; H, 2.93; Br, 29.05; S, 11.66. Found: C, 21.80; H, 3.03; Br, 28.85; S, 12.01 .

\section{References}

Pfeiffer W. D. In Science of Synthesis, Vol. 35; Schaumann E., Ed.; Thieme: Stuttgart, 2007, 423. 